\title{
Qualitative and quantitative comparison of the cytotoxic and apoptotic potential of phytosterol oxidation products with their corresponding cholesterol oxidation products
}

\author{
Eileen Ryan ${ }^{1}$, Jay Chopra ${ }^{2}$, Florence McCarthy ${ }^{2}$, Anita R. Maguire ${ }^{2}$ and Nora M. O’Brien ${ }^{1} *$ \\ ${ }^{1}$ Department of Food and Nutritional Sciences, University College, Cork, Ireland \\ ${ }^{2}$ Department of Chemistry, Analytical and Biological Chemistry Research Facility, University College, Cork, Ireland
}

(Received 2 February 2005 - Revised 6 April 2005 - Accepted 6 April 2005)

\begin{abstract}
Phytosterols contain an unsaturated ring structure and therefore are susceptible to oxidation under certain conditions. Whilst the cytotoxicity of the analogous cholesterol oxidation products (COP) has been well documented, the biological effects of phytosterol oxidation products (POP) have not yet been fully ascertained. The objective of the present study was to examine the cytotoxicity of $\beta$-sitosterol oxides and their corresponding COP in a human monocytic cell line (U937), a colonic adenocarcinoma cell line (CaCo-2) and a hepatoma liver cell line (HepG2). 73-Hydroxysitosterol, 7-ketositosterol, sitosterol$3 \beta, 5 \alpha, 6 \beta$-triol and a sitosterol- $5 \alpha, 6 \alpha$-epoxide-sitosterol-5 $\beta, 6 \beta$-epoxide (6:1) mixture were found to be cytotoxic to all three cell lines employed; the mode of cell death was by apoptosis in the U937 cell line and necrosis in the CaCo-2 and HepG2 cells. 7 $\beta$-Hydroxysitosterol was the only $\beta$-sitosterol oxide to cause depletion in glutathione, indicating that POP-induced apoptosis may not be dependent on the generation of an oxidative stress. A further objective of this study was to assess the ability of the antioxidants $\alpha$-tocopherol, $\gamma$-tocopherol and $\beta$-carotene to modulate POP-induced cytotoxicity in U937 cells. Whilst $\alpha / \gamma$-tocopherol protected against $7 \beta$-hydroxycholesterol-induced apoptosis, they did not confer protection against $7 \beta$-hydroxysitosterolor 7-ketositosterol-induced toxicity, indicating that perhaps COP provoke different apoptotic pathways than POP. $\beta$-Carotene did not protect against COPor POP-induced toxicity. In general, results indicate that POP have qualitatively similar toxic effects to COP. However, higher concentrations of POP are required to elicit comparable levels of toxicity.
\end{abstract}

Phytosterol oxides: Cholesterol oxides: Cytotoxicity: Apoptosis

Plant sterols (phytosterols) are membrane constituents of all plants with a structure analogous to that of cholesterol (zoosterols). Dietary intakes are estimated to be between 160 and $400 \mathrm{mg} / \mathrm{d}$ among different populations and are largely derived from vegetable oils, nuts, seeds and grains (Ostlund, 2002). During the last decade there has been an unprecedented escalation of interest in the potential health benefits of phytosterols, in particular as efficacious cholesterol-lowering agents. Moreover, phytosterols may possess anticarcinogenic, anti-atherosclerotic, anti-inflammatory and anti-oxidative activities (De Jong et al. 2003; Berger et al. 2004). Consequently, esters of phytosterols are being incorporated into a growing spectrum of functional foods such as margarine and salad dressings in a number of countries (Moreau et al. 2002). Dietary intakes are projected to increase accordingly. De Jong et al. (2004) reported that if liberal phytosterol fortification is allowed, the average daily intake might exceed $8.6 \mathrm{~g}$.

Given their structural similarity to cholesterol, it is reasonable to assume that phytosterols are also susceptible to oxidation. The mechanisms of formation of cholesterol oxidation products (COP) are well documented (Tai et al. 1999). Furthermore, evidence exists that several COP may be linked to a series of human diseases, including atherogenesis, cytotoxicity, mutagenesis and carcinogenesis (Brown \& Jessup, 1999). However, data on the mechanism of phytosterol oxidation are very limited, as are data on the level of phytosterol oxidation products (POP) present in food.

Some studies have noted modest amounts of POP in French fries, potato chips and vegetable oils (Lee et al. 1985; Dutta, 1997; Dutta \& Appelqvist, 1997), wheat flour (Nourooz-Zadeh \& Appelqvist, 1992), coffee (Turchetto et al. 1993) and commercial margarine (Grandgirard, 2002). Limited evidence suggests that some POP can pass the intestinal barrier, albeit at a low level (Grandgirard et al. 1999; Tomoyori et al. 2004). Recently, Grandgirard et al. (2004) identified appreciable quantities of oxidised phytosterols in plasma samples of healthy individuals. Two possibilities exist concerning the origin of these compounds in plasma. First, they may stem from absorption of the small amount of POP in food. However, second, their in vivo transformation into phytosterol oxides cannot be excluded. Plat et al. (2001) detected elevated levels of POP in serum of phytosterolaemic patients. In this latter study, phytosterol oxide concentrations in the serum of healthy control samples were below the limit of detection. In an earlier study, Aringer et al. (1976) observed a 27-hydroxylation of campesterol and sitosterol and a 29-hydroxylation of sitosterol in rat liver mitochondria.

Data on biological effects of POP are scarce. Abortifacient effects were described in mice (Pakrashi \& Basak, 1976). 
Meyer \& Spitellier (1997) described an increase in POP during ageing of photoautotrophic cell cultures, as well as cytotoxicity of these compounds in mealworms (Meyer et al. 1998). Adcox et al. (2001) demonstrated that a mixture of POP caused cellular damage in cultured macrophage-derived cells similar to that caused by COP. More recently, Maguire et al. (2003) reported that thermally oxidised derivatives of phytosterols demonstrate similar patterns of toxicity towards a human monocytic cell line (U937) as the COP 7 $\beta$-hydroxycholesterol, but at higher concentrations. The authors describe the evaluation of epoxide prepared by the oxidation of commercial $\beta$-sitosterol (approximately $60 \%$ purity). In view of the projected increase in the consumption of foods enriched with phytosterols, which are known to be liable to oxidation, together with the undesirable health effects attributed to the related COP, additional information on the toxicological significance of POP is warranted.

$\beta$-Sitosterol represents the most abundant phytosterol in nature. Individual oxides of $\beta$-sitosterol were prepared for us by colleagues in the Department of Chemistry, University College Cork. The objective of the present study was to investigate the cytotoxicity and apoptotic potential of individual $\beta$-sitosterol oxides towards a human monocytic blood cell line (U937), a colonic adenocarcinoma cell line $(\mathrm{CaCo}-2)$ and a human hepatoma cell line (HepG2). These cells were employed as U937 cells have previously been shown to undergo apoptosis when treated with certain COP. CaCo-2 cells were used because the gut is the initial site of exposure, absorption and metabolism of dietary components. HepG2 cells retain many functions of the normal liver cell and have been used in many studies evaluating the cytotoxic potential of compounds. For comparison, the cytotoxic effects of the corresponding COP were also assessed in each cell line. The effect of individual POP on cellular glutathione levels was assessed in U937 cells as an index of oxidative stress. A further objective was to assess the ability of some antioxidants commonly found in human diets, i.e. $\alpha$ and $\gamma$-tocopherol and $\beta$-carotene, to modulate POP-induced cytotoxicity.

\section{Materials and methods}

\section{Materials}

All chemicals and cell culture reagents were obtained from Sigma Chemical Co. (Poole, UK) unless otherwise stated. Tissue culture plastics were supplied by Costar (Cambridge, UK). Cell lines were obtained from the European Collection of Animal Cell Cultures (Sailsbury, UK). Information on the purity of the cholesterol oxides (purity $>95 \%$ ) was obtained from Sigma.

\section{Cell maintenance}

Human monocytic U937 cells were grown in suspension in RPMI 1640 medium supplemented with 2 mM-L-glutamine and $10 \%(\mathrm{v} / \mathrm{v})$ fetal calf serum (FCS). Human colonic adenocarcinoma $\mathrm{CaCo}-2$ cells were maintained in Dulbecco's modified Eagle's medium supplemented with $10 \%$ (v/v) FCS, 2 mM-L-glutamine and $1 \%$ non-essential amino-acids. HepG2, a human hepatoma cell line, was grown in Williams E medium supplemented with $2 \mathrm{~mm}-\mathrm{L}$-glutamine and $10 \%(\mathrm{v} / \mathrm{v})$ FCS. The cells were grown at $37^{\circ} \mathrm{C}$ and $5 \%(\mathrm{v} / \mathrm{v}) \mathrm{CO}_{2}$ in a humidified incubator. Cells were screened for mycoplasm contamination by the
Hoechst staining method (Mowels, 1990) and were cultured in the absence of antibiotics. Exponentially growing cells were used throughout the experiments.

\section{Production of $\beta$-sitosterol oxides}

Individual POP are not commercially available and therefore were synthesised, purified and characterised by the Analytical and Biological Chemistry Research Facility (ABCRF) Department of Chemistry, University College Cork (McCarthy et al. 2005). The target compounds were sitosterol-5 $5,6 \alpha$-epoxide ( $\alpha$-epoxysitosterol), synthesised as previously described by Maguire et al. (2003) sitosterol-5 $\beta, 6 \beta$-epoxide ( $\beta$-epoxysitosterol), 7 $\beta$-hydroxysitosterol, 7-ketositosterol and sitosterol$3 \beta, 5 \alpha, 6 \beta$-triol (triolsitosterol). The first objective was to obtain $\beta$-sitosterol with the best possible purity, in order to prepare unambiguous phytosterol oxides. Pure $\beta$-sitosterol (approximately $98.9 \%$ purity) was synthesised from stigmasterol of approximately $95 \%$ purity from Sigma-Aldrich. The strategy for the synthesis of $\beta$-sitosterol from stigmasterol involved the protection of the double bond in the $\beta$-ring followed by hydrogenation of the side-chain double bond. Ethanol was employed as the solvent and $\mathrm{Pd}-\mathrm{C}$ as the catalyst at $345 \mathrm{kPa}$ pressure. This was then followed by deprotection of the methyl ether to give $\beta$-sitosterol of approximately $98.9 \%$ purity as defined by GC-MS and NMR spectroscopy. The second objective was to synthesise the target oxidation products from this pure $\beta$-sitosterol. The procedures followed in this work were very similar to those employed by $\mathrm{Li} \&$ Wilson (1999) for the synthesis of COP.

\section{Cell treatment with $\beta$-sitosterol oxides}

For experiments, U937 cells, CaCo-2 cells or HepG2 cells were adjusted to a density of $2 \times 10^{5}$ cells $/ \mathrm{ml}$ supplemented with reduced serum media, $2.5 \%(\mathrm{v} / \mathrm{v})$ FCS. Oxides of $\beta$-sitosterol were added to the tissue culture medium at the concentration of $30 \mu \mathrm{M}, 60 \mu \mathrm{M}$ or $120 \mu \mathrm{M}$. For comparison, cells were also incubated with $30 \mu \mathrm{M}$ of the corresponding cholesterol oxides, namely, cholesterol- $5 \alpha, 6 \alpha$-epoxide ( $\alpha$-epoxycholesterol), cholesterol- $5 \beta, 6 \beta$-epoxide ( $\beta$-epoxycholesterol), 7 $\beta$-hydroxycholesterol, 7-ketocholesterol and cholestane-3 $3 \beta, 5 \alpha, 6 \beta$-triol (triolcholesterol). All compounds were dissolved in ethanol and the final concentration in the cultures did not exceed $0.4 \%$ (v/ v). Equivalent quantities of ethanol were added to control cells and samples were incubated for $24 \mathrm{~h}$ at $37^{\circ} \mathrm{C}$ and $5 \%(\mathrm{v} / \mathrm{v})$ $\mathrm{CO}_{2}$. A concentration of $30 \mu \mathrm{M}$ COP was selected for this study as it approximates the upper physiological concentration found in human plasma. Emanuel et al. (1991) reported a concentration as high as $37 \mu \mathrm{M}$ in human plasma, following the ingestion of a test meal of spray-dried powdered eggs. Since this study is a comparative study of the cytotoxic and apoptotic potential of POP with their corresponding COP, the phytosterol oxides were used at concentrations as high as $120 \mu \mathrm{M}$ as this is the concentration that showed similar toxic effects to the COP. The concentration of POP used in our in vitro models is higher than those encountered physiologically. Plat et al. (2001) reported $7 \beta$-hydroxysitosterol concentrations about $2 \mu \mathrm{M}$ and slightly higher concentrations for 7-ketositosterol in serum from phytosterolaemic patients. 
Treatment of U937 cells with $\beta$-sitosterol oxides in the presence of $\alpha / \gamma$-tocopherol or $\beta$-carotene

U937 cells were adjusted to a density of $2 \times 10^{5}$ cells $/ \mathrm{ml}$ supplemented with reduced serum media, $2.5 \%(\mathrm{v} / \mathrm{v})$ FCS. Cells were treated with $10 \mu \mathrm{M}$ of $\alpha$-tocopherol or $\gamma$-tocopherol or $2 \mu \mathrm{M}-\beta$-carotene for $1 \mathrm{~h}$ at $37^{\circ} \mathrm{C}$ and $5 \%$ (v/v) $\mathrm{CO}_{2}$. Subsequently, cells were treated with $30 \mu \mathrm{M}-7 \beta$-hydroxycholesterol or $120 \mu \mathrm{M}$ $7 \beta$-hydroxysitosterol or 7-ketositosterol. All compounds were dissolved (with the exception of $\beta$-carotene) in ethanol and the final concentration in the cultures did not exceed $0.4 \%(\mathrm{v} / \mathrm{v})$. $\beta$-Carotene was dissolved in hexane and the final concentration in the cultures did not exceed $0.4 \%(\mathrm{v} / \mathrm{v})$. Equivalent quantities of ethanol/hexane were added to the control cells. To determine if the tocopherols or $\beta$-carotene had any effect on toxicity, the cells were also incubated with these compounds alone. Samples were incubated for $24 \mathrm{~h}$ at $37^{\circ} \mathrm{C}$ and $5 \%(\mathrm{v} / \mathrm{v}) \mathrm{CO}_{2}$.

\section{Cell viability}

The viability of the U937 cells was assessed after $24 \mathrm{~h}$ by the flurochrome-mediated viability assay as previously described by Strauss (1991). Briefly, cells were mixed 1:1 (v/v) with a solution of fluorescein diacetate and ethidium bromide, then incubated at $37^{\circ} \mathrm{C}$ for $5 \mathrm{~min}$ before being layered onto a microscope slide. Under these conditions, viable cells fluoresce green, whereas non-viable cells fluoresce red. Samples were examined at $\times 200$ magnification on a Nikon fluorescence microscope (The micron optical Co. Ltd., Enriscorthy, Co. Wexford, Ireland) using blue light $(450-490 \mathrm{~nm})$. Two hundred cells were scored from each slide and cell viability was expressed as the percentage of viable (green) cells.

The viability of the CaCo- 2 and HepG2 cells was assessed after $24 \mathrm{~h}$ by the Neutral Red uptake assay as described by Borenfreund \& Puerner (1984). The Neutral Red uptake assay was chosen for the CaCo-2 and HepG2 cells as both are adherent cell lines and this is the most suitable viability assay for adherent cells. Whilst the fluorescein diacetate/ethidium bromide assay can be employed as a viability assay for the CaCo-2 and HepG2 cells, it would have involved scraping the cells and we felt this step might result in over- or underestimating the ratio of viable to non-viable cells. Following treatments, medium was removed from the cells. Neutral Red dye $(50 \mu \mathrm{g} / \mathrm{ml}$ complete medium) was added to each well of the six-well plate and incubated for $2 \mathrm{~h}$ at $37^{\circ} \mathrm{C}$ and $5 \%(\mathrm{v} / \mathrm{v}) \mathrm{CO}_{2}$ to allow for uptake of the dye into the lysosomes of viable uninjured cells. The medium was removed and cells were washed with Krebs buffer. The cells were subsequently treated with $2 \mathrm{ml}$ of $1 \%$ glacial acetic acid/ $50 \%$ ethanol to burst cells open and release the dye. After agitation for a few minutes on a plate shaker, the samples were transferred to microcuvettes and absorbance was determined spectrophotometrically $(540 \mathrm{~nm})$.

\section{Morphological analysis of cell nuclei}

Nuclear morphology of control and oxysterol-treated cells was assessed by fluorescence microscopy after staining with Hoechst 33342. Approximately $4 \times 10^{5}$ cells were centrifuged at $200 \mathrm{~g}$ for $10 \mathrm{~min}$ to form a pellet. Hoechst 33342 stain $(200 \mu \mathrm{l}, 5 \mu \mathrm{g} /$ $\mathrm{ml}$ ) was added and the samples were incubated at $37^{\circ} \mathrm{C}$ and $5 \%$ (v/v) $\mathrm{CO}_{2}$ for $1 \mathrm{~h}$. Stained samples were placed on a microscope slide and examined under UV light (Nikon Labophot fluorescence microscope, $\times 400$ magnification; The Micron Optical Co. Ltd.). A total of 300 cells per sample were analysed and the percentage of fragmented and condensed nuclei was calculated. Apoptotic cells were characterised by nuclear condensation of chromatin and/or nuclear fragmentation (Dubrez et al. 1996).

\section{DNA fragmentation assay}

Detection of small DNA fragments was conducted as described in O'Callaghan et al. (1999). Briefly, $2 \times 10^{6}$ cells were harvested and the pellets were lysed, RNAse A $(0.25 \mathrm{mg} / \mathrm{ml})$ was added and the samples incubated at $50^{\circ} \mathrm{C}$ for $1 \mathrm{~h}$. Proteinase $\mathrm{K}(5 \mathrm{mg}$ / $\mathrm{ml}$ ) was added and the samples were incubated at $50^{\circ} \mathrm{C}$ for a further $1 \mathrm{~h}$ before being loaded into the wells of a $1.5 \%(\mathrm{w} / \mathrm{v})$ agarose gel. A 100-1500 bp DNA standard (Promega; Medical Supply Co. Ltd, Dublin, Ireland) was used to assess DNA fragmentation. Electrophoresis was carried out in agarose gels prepared in tri(hydroxymethyl)aminomethane-borate-EDTA buffer at $0 \cdot 3 \mathrm{~V} / \mathrm{mm}$. DNA was visualised under UV light on a transilluminator $(312 \mathrm{~nm})$ after ethidium bromide staining and photographed using a digital camera (Kodak; Anacherm Ltd, Dublin, Ireland).

\section{Determination of cellular glutathione levels}

The cellular level of glutathione was measured according to the method of Hissin \& Hilf (1976). Briefly $2 \times 10^{5}$ cells were centrifuged at $100000 \mathrm{~g}$ for $25 \mathrm{~min}$. Supernatant $(100 \mu \mathrm{l})$ was diluted in $1.8 \mathrm{ml}$ phosphate-EDTA buffer $\left(0.1 \mathrm{~mol} \mathrm{Na}_{2} \mathrm{PO}_{3} / \mathrm{l}, 0.005 \mathrm{~mol}\right.$ EDTA/l, pH 8) and mixed with $100 \mu \mathrm{l} o$-phthaldaldehyde $(1 \mu \mathrm{g} /$ $\mu 1)$. Samples were incubated at $25^{\circ} \mathrm{C}$ for $15 \mathrm{~min}$ and the fluorescence was detected at $420 \mathrm{~nm}$ following activation at $350 \mathrm{~nm}$. The glutathione concentration of the samples was determined from a standard curve. Results were adjusted for protein content (Smith et al. 1985) and expressed as a percentage of the control.

\section{Statistical analysis}

All data points are the mean values of at least three independent experiments. Data were analysed by ANOVA followed by Dunnett's test. The software employed for statistical analysis was Prism (Hearne Scientific Software, Dublin, Ireland).

\section{Results}

\section{Effect of $\beta$-sitosterol oxides on cell viability}

Viability was assessed in U937 cells by the fluorescein diacetate/ ethidium bromide method following exposure to $\beta$-sitosterol oxides for $24 \mathrm{~h}$. Viability in the control samples was above $90 \%$ for all experiments. The phytosterol oxides caused no observable change in cell viability at the lower concentration of $30 \mu \mathrm{M}$ (Table 1). In contrast, $30 \mu \mathrm{M}-\beta$-epoxycholesterol, $7 \beta$-hydroxycholesterol, 7-ketocholesterol and triolcholesterol caused a significant reduction $(P<0.001)$ in viable cells to $73,77,67$ and $13 \%$, respectively. Exposure to $60 \mu \mathrm{M}$ of $7 \beta$-hydroxysitosterol resulted in a significant decrease $(P<0 \cdot 001)$ in cell viability to $83 \%$. All other phytosterol oxides had no significant effect on cell viability at this concentration. At $120 \mu \mathrm{M}$, both $7 \beta$-hydroxysitosterol and 7-ketositosterol significantly reduced $(P<0.001)$ cell viability to 
Table 1. Percentage of viable cells following exposure for $24 \mathrm{~h}$ to 30,60 or $120 \mu \mathrm{M} \alpha$-epoxysitosterol ( $\alpha$-epox), $\beta$-epoxysitosterol ( $\beta$-epox), $\alpha$-epoxysitosterol- $\beta$-epoxysitosterol (6:1) mixture $(\alpha / \beta$-epox), $7 \beta$-hydroxysitosterol (7 $\beta$ $\mathrm{OH}), 7$-ketositosterol (7-keto) or triolsitosterol (triol). Cells were also treated with $30 \mu \mathrm{M}$ of the corresponding cholesterol oxides (chol). All compounds were dissolved in ethanol and equivalent quantities of ethanol (EtOH) were added to control cells. Viability of the U937 cells was assessed by the fluorescein diacetate/ethidium bromide assay; viability of the CaCo-2 and HepG2 cells was assessed via the Neutral Red uptake assay

(Values are means with their standard errors of at least three independent experiments)

\begin{tabular}{|c|c|c|c|c|c|c|}
\hline \multirow[b]{3}{*}{ Compound } & \multicolumn{6}{|c|}{$\%$ Cell viability } \\
\hline & \multicolumn{2}{|c|}{ U937 cells } & \multicolumn{2}{|c|}{ CaCo-2 cells } & \multicolumn{2}{|c|}{ HepG2 cells } \\
\hline & Mean & SE & Mean & SE & Mean & SE \\
\hline Control (EtOH) & $98 \cdot 2$ & 0.3 & $100 \cdot 0$ & 0.0 & $100 \cdot 0$ & 0.0 \\
\hline $30 \mu \mathrm{M}-\alpha$-ерох & 94.0 & 0.9 & $102 \cdot 6$ & $1 \cdot 2$ & $110 \cdot 6$ & 3.9 \\
\hline $60 \mu \mathrm{M}-\alpha$-ерох & $94 \cdot 3$ & $1 \cdot 2$ & $101 \cdot 1$ & $2 \cdot 2$ & $107 \cdot 4$ & $4 \cdot 6$ \\
\hline $120 \mu \mathrm{M}-\alpha$-ерох & $95 \cdot 4$ & $1 \cdot 1$ & $101 \cdot 1$ & 4.4 & $107 \cdot 3$ & 4.5 \\
\hline $30 \mu \mathrm{M}-\alpha$-epox chol & $89 \cdot 0$ & 4.5 & 98.9 & 3.6 & $98 \cdot 2$ & $2 \cdot 2$ \\
\hline Control (EtOH) & $97 \cdot 6$ & 0.7 & $100 \cdot 0$ & 0.0 & $100 \cdot 0$ & 0.0 \\
\hline $30 \mu \mathrm{M}-\beta$-ерох & $97 \cdot 0$ & 0.9 & $111 \cdot 7$ & 3.5 & $100 \cdot 2$ & $2 \cdot 6$ \\
\hline $60 \mu \mathrm{M}-\beta$-ерох & $94 \cdot 3$ & $1 \cdot 3$ & $110 \cdot 2$ & $4 \cdot 7$ & 101.5 & $4 \cdot 8$ \\
\hline $120 \mu \mathrm{M}-\beta$-ерох & $91 \cdot 0^{*}$ & 0.7 & $109 \cdot 0$ & 0.6 & $99 \cdot 2$ & 1.8 \\
\hline $30 \mu \mathrm{M}-\beta$-epox chol & $72 \cdot 8^{\star *}$ & 1.4 & $63.9^{*}$ & $7 \cdot 0$ & $57 \cdot 6^{\star}$ & $7 \cdot 0$ \\
\hline Control $(\mathrm{EtOH})$ & 93.8 & $2 \cdot 0$ & $100 \cdot 0$ & 0.0 & $100 \cdot 0$ & 0.0 \\
\hline $30 \mu \mathrm{M}-\alpha / \beta$-epox & $90 \cdot 7$ & $3 \cdot 6$ & $103 \cdot 8$ & $2 \cdot 6$ & 94.9 & $3 \cdot 0$ \\
\hline $60 \mu \mathrm{M}-\alpha / \beta$-epox & $96 \cdot 4$ & 0.9 & 96.6 & 3.2 & 89.9 & 2.5 \\
\hline $120 \mu \mathrm{M}-\alpha / \beta$-ерох & $77 \cdot 4$ & $10 \cdot 2$ & $76 \cdot 7^{\star}$ & 5.6 & $73 \cdot 2^{\star \star}$ & $8 \cdot 4$ \\
\hline Control (EtOH) & $98 \cdot 2$ & 0.3 & $100 \cdot 0$ & 0.0 & $100 \cdot 0$ & 0.0 \\
\hline $30 \mu \mathrm{M}-7 \beta-\mathrm{OH}$ & $93 \cdot 3$ & $1 \cdot 7$ & $91 \cdot 6$ & 11.7 & $76 \cdot 9$ & $13 \cdot 2$ \\
\hline $60 \mu \mathrm{M}-7 \beta-\mathrm{OH}$ & $82 \cdot 7^{\star *}$ & $1 \cdot 2$ & $61 \cdot 9^{*}$ & $9 \cdot 1$ & $13 \cdot 1^{\star *}$ & $2 \cdot 1$ \\
\hline $120 \mu \mathrm{M}-7 \beta-\mathrm{OH}$ & $64 \cdot 7^{\star *}$ & $6 \cdot 2$ & $40 \cdot 8^{\star \star}$ & 4.0 & $4 \cdot 6^{\star *}$ & 0.7 \\
\hline $30 \mu \mathrm{M}-7 \beta-\mathrm{OH}$ chol & $76 \cdot 7^{\star *}$ & $2 \cdot 1$ & $88 \cdot 8^{*}$ & 0.3 & $87 \cdot 3$ & $3 \cdot 3$ \\
\hline Control (EtOH) & $98 \cdot 2$ & 0.3 & $100 \cdot 0$ & 0.0 & $100 \cdot 0$ & 0.0 \\
\hline $30 \mu \mathrm{M}-7-$ keto & $94 \cdot 7$ & 0.7 & $93 \cdot 0$ & $4 \cdot 7$ & $84 \cdot 7$ & $7 \cdot 7$ \\
\hline $60 \mu \mathrm{M}-7-$ keto & 88.5 & $2 \cdot 4$ & $64 \cdot 4^{\star \star}$ & $7 \cdot 0$ & $26 \cdot 7^{\star \star}$ & $15 \cdot 1$ \\
\hline $120 \mu \mathrm{M}$-7-keto & $64 \cdot 7^{\star \star}$ & $6 \cdot 2$ & $23 \cdot 3^{\star \star}$ & $4 \cdot 2$ & $7 \cdot 1^{* *}$ & $3 \cdot 1$ \\
\hline $30 \mu \mathrm{M}$-7-keto chol & $67 \cdot 2^{\star \star}$ & $7 \cdot 3$ & $82 \cdot 9^{\star}$ & $6 \cdot 1$ & 86.5 & 4.5 \\
\hline Control (EtOH) & $95 \cdot 5$ & $1 \cdot 2$ & $100 \cdot 0$ & 0.0 & $100 \cdot 0$ & 0.0 \\
\hline $30 \mu \mathrm{M}$-triol & 92.5 & $4 \cdot 1$ & $97 \cdot 1$ & 0.9 & $90 \cdot 3$ & $7 \cdot 7$ \\
\hline $60 \mu \mathrm{M}$-triol & 94.5 & $1 \cdot 1$ & $78 \cdot 6$ & $9 \cdot 2$ & $81 \cdot 6$ & $5 \cdot 1$ \\
\hline $120 \mu \mathrm{M}$-triol & $59 \cdot 6^{*}$ & $7 \cdot 6$ & $54 \cdot 8^{\star \star}$ & 13.6 & $65 \cdot 5^{\star *}$ & 9.8 \\
\hline $30 \mu \mathrm{M}$-triol chol & $12 \cdot 9^{\star *}$ & 2.5 & $3 \cdot 0^{\star \star}$ & 1.7 & $10 \cdot 6^{\star *}$ & $5 \cdot 2$ \\
\hline
\end{tabular}

Mean values were significantly different from those of the control group (ANOVA followed by Dunnett's test): ${ }^{\star} P<0.05,{ }^{\star \star} P<0.001$.

$65 \%$. Exposure to $120 \mu \mathrm{M}$ - $\beta$-epoxysitosterol or $120 \mu \mathrm{M}$-triolsitosterol caused a significant decrease $(P<0.05)$ in viable cells to 91 and $60 \%$, respectively. The $\alpha$-epoxysitosterol was not toxic to the U937 cells at any of the concentrations tested.

Viability in the CaCo-2 cells was assessed by the Neutral Red uptake assay following exposure to the oxides for $24 \mathrm{~h}$. Viability in the control samples was set at $100 \%$. The phytosterol oxides caused no observable change in cell viability at the lower concentration of $30 \mu \mathrm{M}$ (Table 1). In contrast, $30 \mu \mathrm{M}-\beta$-epoxycholesterol, $7 \beta$-hydroxycholesterol and 7-ketocholesterol caused a significant reduction $(P<0.05)$ in viable cells to 64,89 and $83 \%$, respectively. Triolcholesterol, at $30 \mu \mathrm{M}$, caused a considerable reduction $(P<0 \cdot 001)$ in cell viability to $3 \%$. Exposure to $60 \mu \mathrm{M} 7 \beta$-hydroxysitosterol resulted in a significant decrease $(P<0.05)$ in cell viability to $62 \%$, whilst $60 \mu \mathrm{M}-7$-ketositsoterol significantly reduced $(P<0.001)$ cell viability to $64 \%$. All other phytosterol oxides had no significant effect on cell viability at this concentration. At $120 \mu \mathrm{M}, 7 \beta$-hydroxysitosterol, 7-ketositosterol and triolsitosterol significantly reduced $(P<0.001)$ cell viability to
41,23 and $55 \%$, respectively. The $\alpha$-epoxysitosterol- $\beta$-epoxysitosterol mixture $(6: 1)$, at $120 \mu \mathrm{M}$, also caused a significant decrease $(P<0.05)$ in viable cells to $77 \%$. At all concentrations tested, $\beta$-epoxysitosterol and $\alpha$-epoxysitosterol were not toxic to the $\mathrm{CaCo}-2$ cells.

Viability in the HepG2 cells was also assessed by the Neutral Red uptake assay following exposure to the oxides for $24 \mathrm{~h}$. Viability in the control samples was set at $100 \%$. The phytosterol oxides caused no observable change in cell viability at the lower concentration of $30 \mu \mathrm{M}$. In contrast, $30 \mu \mathrm{M}-\beta$-epoxycholesterol caused a significant reduction $(P<0.05)$ in viable cells to $58 \%$ whilst triolcholesterol, at $30 \mu \mathrm{M}$, caused a considerable reduction $(P<0.001)$ in cell viability to $11 \%$. Exposure to $60 \mu \mathrm{M}-7 \beta$-hydroxsitosterol or $60 \mu \mathrm{M}$-7-ketositosterol resulted in a significant decrease $(P<0.001)$ in cell viability to 13 and $27 \%$, respectively. All other phytosterol oxides had no significant effect on cell viability at this concentration. At $120 \mu \mathrm{M}, 7 \beta$-hydroxysitosterol and 7-ketositosterol significantly reduced $(P<0 \cdot 001)$ cell viability to 5 and $7 \%$. Triolsitosterol and $\alpha$-epoxysitosterol$\beta$-epoxysitosterol, at $120 \mu \mathrm{M}$, also caused a significant decrease $(P<0.001)$ in viable cells to 66 and $73 \%$, respectively. As with the $\mathrm{CaCo}-2$ cells, $\beta$-epoxysitosterol and $\alpha$-epoxysitosterol were not toxic to the HepG2 cells.

\section{Effect of $\beta$-sitosterol oxides on induction of apoptosis}

Condensed and fragmented nuclei were determined by morphological examination following staining with Hoechst 33342. Nuclei, which were condensed or fragmented, were identified as apoptotic cells. The apoptotic cells did not exceed $3.1 \%$ in the control cells (Table 2). The phytosterol oxides caused no observable change in the percentage of apoptotic nuclei at the lower concentration of $30 \mu \mathrm{M}$. In contrast, exposure to $30 \mu \mathrm{M}-7 \beta$-hydroxycholesterol, 7-ketocholesterol, $\beta$-epoxycholesterol and triolcholesterol resulted in a significant increase in apoptotic nuclei to $11 \%(P<0.001), 11 \%(P<0.05), 12 \%(P<0.001)$ and $15 \%$ $(P<0.001)$, respectively. Following incubation with $60 \mu \mathrm{M}-7 \beta-$ hydroxysitosterol, there was a significant increase $(P<0 \cdot 001)$ in apoptotic nuclei to $12 \%$, whilst $60 \mu \mathrm{M}$-7-ketositosterol significantly increased $(P<0.05)$ apoptotic nuclei to $17 \%$. All other phytosterol oxides did not induce apoptosis at this concentration. At $120 \mu \mathrm{M}$, both 7 $\beta$-hydroxysitosterol and 7-ketositosterol significantly increased $(P<0.001)$ apoptotic nuclei to 19 and $40 \%$, respectively, and produced a ladder-like pattern on agarose gels (Fig. 1). Exposure to $120 \mu \mathrm{M} \alpha$-epoxysitosterol- $\beta$-epoxysitosterol or $120 \mu \mathrm{M}$ triolsitosterol caused a significant increase $(P<0.05)$ in apoptotic nuclei to 21 and $10 \%$, respectively. For the latter treatment groups, DNA ladders were evident on the agarose gel (Fig. 1). Whilst $\beta$-epoxysitosterol caused a significant increase in apoptotic nuclei to $7 \%$, it failed to produce a ladderlike pattern on agarose (Fig. 1). At all concentrations tested, $\alpha-$ epoxysitosterol did not induce apoptosis nor was any DNA laddering evident (Fig. 1). There was no evidence of apoptosis in either the $\mathrm{CaCo}-2$ or the HepG2 cell line under any of the experimental conditions in the present study (data not shown).

\section{Ability of antioxidants to modulate phytosterol oxidation product- induced toxicity}

To assess the ability of the antioxidants $\alpha$-tocopherol, $\gamma$-tocopherol and $\beta$-carotene to modulate $7 \beta$-hydroxysitosterol- or 
Table 2. Percentage of condensed or fragmented nuclei in U937 cells following exposure for $24 \mathrm{~h}$ to 30,60 or $120 \mu \mathrm{M} \alpha$-epoxysitosterol ( $\alpha$-epox), $\beta$-epoxysitosterol ( $\beta$-epox), $\alpha$-epoxysitosterol- $\beta$-epoxysitosterol (6:1) mixture ( $\alpha / \beta$-epox), $7 \beta$-hydroxysitosterol $(7 \beta-\mathrm{OH}), 7$-ketositosterol (7-keto) or triolsitosterol (triol). Cells were also treated with $30 \mu \mathrm{M}$ of the corresponding cholesterol oxides (chol). All compounds were dissolved in ethanol and equivalent quantities of ethanol (EtOH) were added to control cells. The morphology of the nuclei was assessed using Hoechst 33342 stain (see p. 445), and the number of apoptotic nuclei expressed as a percentage of the total number

(Values are means with their standard errors of at least three independent experiments)

\begin{tabular}{|c|c|c|c|c|c|c|c|c|c|c|}
\hline \multirow[b]{3}{*}{ Compound } & \multicolumn{10}{|c|}{ \% Apoptotic nuclei in U937 cells } \\
\hline & \multicolumn{2}{|c|}{$\begin{array}{l}\text { Control } \\
(\mathrm{EtOH})\end{array}$} & \multicolumn{2}{|c|}{$30 \mu \mathrm{M}$} & \multicolumn{2}{|c|}{$60 \mu \mathrm{M}$} & \multicolumn{2}{|c|}{$120 \mu \mathrm{M}$} & \multicolumn{2}{|c|}{$30 \mu \mathrm{M}$ chol } \\
\hline & Mean & SE & Mean & SE & Mean & SE & Mean & $\mathrm{SE}$ & Mean & SE \\
\hline$\alpha$-epox & 1.6 & 0.3 & $3 \cdot 1$ & 0.5 & $2 \cdot 9$ & $1 \cdot 2$ & $2 \cdot 4$ & 0.7 & 3.4 & $1 \cdot 2$ \\
\hline$\beta$-ерох & $3 \cdot 1$ & 0.4 & $2 \cdot 1$ & 0.8 & $4 \cdot 0$ & 0.8 & $7 \cdot 0^{*}$ & 0.6 & $12 \cdot 2^{\star \star}$ & 0.6 \\
\hline$\alpha / \beta$-ерох & 1.6 & 0.3 & $1 \cdot 8$ & 0.4 & $5 \cdot 6$ & $2 \cdot 2$ & $20 \cdot 9^{\star \star}$ & $5 \cdot 0$ & - & - \\
\hline $7 \beta-\mathrm{OH}$ & 1.9 & 0.1 & 5.9 & $2 \cdot 1$ & $12 \cdot 3^{\star \star}$ & $2 \cdot 2$ & $19 \cdot 4^{\star \star}$ & 1.9 & $11 \cdot 3^{\star *}$ & 0.9 \\
\hline 7-keto & 1.9 & 0.1 & 3.0 & 0.2 & $17 \cdot 1^{*}$ & 4.9 & $39 \cdot 7^{\star *}$ & 3.8 & $11 \cdot 1^{*}$ & $1 \cdot 2$ \\
\hline triol & 0.6 & 0.4 & 0.8 & 0.4 & $2 \cdot 1$ & 0.7 & $9 \cdot 5^{\star}$ & $2 \cdot 3$ & $14 \cdot 8^{\star \star}$ & $2 \cdot 8$ \\
\hline
\end{tabular}

Mean values were significantly different from those of the control group (ANOVA followed by Dunnett's test): ${ }^{\star} P<0.05,{ }^{\star \star} P<0.001$.

7-ketositosterol-induced toxicity, U937 cells were first treated with the antioxidants for $1 \mathrm{~h}$ and subsequently treated with the oxides for $24 \mathrm{~h}$. Viability was assessed via the fluorescein diacetate/ethidium bromide assay whilst condensed and fragmented nuclei were determined by staining with Hoechst 33342 . Viability in the control samples was above $90 \%$ for all experiments (Table 3). Apoptotic nuclei did not exceed $4 \%$ in the controls. Cell treatment with tocopherols or $\beta$-carotene alone had no effect on cell viability or apoptotic nuclei. Exposure of U937

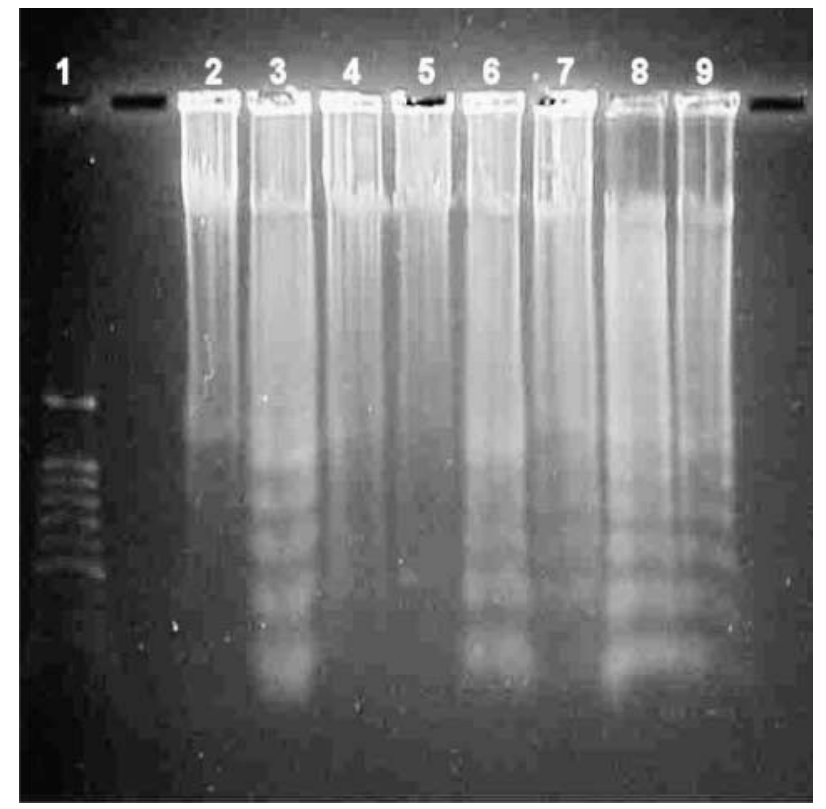

Fig. 1. Induction of DNA fragmentation following incubation for $24 \mathrm{~h}$ with $30 \mu \mathrm{M} 7 \beta$-hydroxycholesterol $(7 \beta-\mathrm{OH}$ chol) or $120 \mu \mathrm{M} \alpha$-epoxysitosterol $(\alpha-$ epox), $\beta$-epoxysitosterol ( $\beta$-epox), $\alpha$-epoxysitosterol- $\beta$-epoxysitosterol $(6: 1)$ mixture $(\alpha / \beta$-epox), triolsitosterol (triol), 7-ketositosterol (7-keto) or $7 \beta$-hydroxysitosterol $(7 \beta-O H)$. DNA fragmentation was assessed by agarose gel electrophoresis. Lane 1, molecular weight marker; lane 2, solvent control; lane 3 , $7 \beta-\mathrm{OH}$ chol; lane $4, \alpha$-epox; lane $5, \beta$-epox; lane $6, \alpha / \beta$-epox; lane 7 , triol; lane 8, 7-keto; lane 9, 7ß-OH. cells to $30 \mu \mathrm{M}-7 \beta$-hydroxycholesterol significantly decreased $(P<0.001)$ viable cells to $71 \%$ and significantly increased $(P<0.001)$ the condensed and fragmented nuclei to $15 \%$. When $7 \beta$-hydroxycholesterol and the tocopherols were co-incubated $(30 \mu \mathrm{M} / 10 \mu \mathrm{M})$, both $\alpha$-tocopherol and $\gamma$-tocopherol inhibited the decrease in viable cells and the increase in apoptotic nuclei induced by the COP. Treatment of U937 cells with $120 \mu \mathrm{M}$ of

Table 3. Effect of $\alpha$-tocopherol ( $\alpha$-TOC), $\gamma$-tocopherol $(\gamma$-TOC) and $\beta$-carotene ( $\beta$-Car) on $7 \beta$-hydroxycholesterol $(7 \beta-\mathrm{OH}$ chol)-, $7 \beta$-hydroxysitosterol (7 $\beta-\mathrm{OH})$ - and 7-ketositosterol (7-keto)induced toxicity. U937 cells were treated with $\alpha$-TOC $(10 \mu \mathrm{M})$, $\gamma$-TOC $(10 \mu \mathrm{M})$ or $\beta$-Car $(2 \mu \mathrm{M})$ for $1 \mathrm{~h}$. Subsequently, the cells were treated with $7 \beta-\mathrm{OH}$ chol $(30 \mu \mathrm{M}), 7 \beta-\mathrm{OH}(120 \mu \mathrm{M})$ or 7 -keto $(120 \mu \mathrm{M})$ for $24 \mathrm{~h}$. Samples were processed either for cell viability or stained with Hoechst 33342 and analysed by fluorescence microscopy (see p. 445)

(Values are means with their standard errors of at least three independent experiments)

\begin{tabular}{|c|c|c|c|c|}
\hline \multirow[b]{2}{*}{ Treatment } & \multicolumn{2}{|c|}{$\%$ Viable cells } & \multicolumn{2}{|c|}{$\begin{array}{c}\% \text { Apoptotic } \\
\text { nuclei }\end{array}$} \\
\hline & Mean & $\mathrm{SE}$ & Mean & $\mathrm{SE}$ \\
\hline Control (ethanol) & $97 \cdot 4$ & $1 \cdot 3$ & 3.0 & $0 \cdot 1$ \\
\hline Control (hexane) & 91.4 & $3 \cdot 2$ & 3.9 & $1 \cdot 2$ \\
\hline$\alpha$-TOC & 98.4 & 0.7 & $2 \cdot 2$ & 0.2 \\
\hline$\beta$-TOC & $97 \cdot 5$ & 0.4 & 2.9 & 0.2 \\
\hline$\beta$-Car & $97 \cdot 3$ & 1.0 & $3 \cdot 1$ & 0.5 \\
\hline $30 \mu \mathrm{m}-7 \beta-\mathrm{OH}$ chol & $70 \cdot 5^{\star \star}$ & $2 \cdot 7$ & $15 \cdot 2^{\text {** }}$ & 1.3 \\
\hline $7 \beta-\mathrm{OH}$ chol $/ \alpha-\mathrm{TOC}$ & $89 \cdot 8$ & 0.9 & $4 \cdot 0$ & 0.5 \\
\hline $7 \beta-\mathrm{OH} \mathrm{chol} / \gamma-\mathrm{TOC}$ & 88.5 & 4.4 & $6 \cdot 6$ & $2 \cdot 3$ \\
\hline $7 \beta-\mathrm{OH}$ chol $/ \beta-\mathrm{Car}$ & $77 \cdot 9^{\star *}$ & $6 \cdot 1$ & $13 \cdot 1^{\text {** }}$ & $1 \cdot 6$ \\
\hline $120 \mu \mathrm{m}-7 \beta-\mathrm{OH}$ & $54 \cdot 9^{\star \star}$ & $2 \cdot 6$ & $24 \cdot 5^{\star \star}$ & 2.5 \\
\hline $7 \beta-\mathrm{OH} / \beta-\mathrm{TOC}$ & $60 \cdot 4^{\star *}$ & $4 \cdot 4$ & $21 \cdot 2^{\star *}$ & $3 \cdot 1$ \\
\hline $7-\mathrm{OH} / \gamma-\mathrm{TOC}$ & $59 \cdot 1^{\star \star}$ & 4.5 & $25 \cdot 0^{\star *}$ & 3.9 \\
\hline $7 \beta-\mathrm{OH} / \beta-\mathrm{Car}$ & $62 \cdot 4^{\star \star}$ & $2 \cdot 4$ & $20 \cdot 1^{\text {** }}$ & $1 \cdot 0$ \\
\hline $120 \mu \mathrm{m}$-7-keto & $73 \cdot 9^{\star \star}$ & $2 \cdot 6$ & $26 \cdot 1^{\text {** }}$ & $1 \cdot 5$ \\
\hline 7-keto/ $\alpha$-TOC & $84 \cdot 8^{*}$ & 2.5 & $20 \cdot 6^{\star \star}$ & $2 \cdot 0$ \\
\hline 7-keto/ $\gamma$-TOC & $79 \cdot 5^{\star \star}$ & 0.3 & $24 \cdot 0^{\star *}$ & 1.5 \\
\hline 7-keto/ $\beta$-Car & $75 \cdot 7^{\star \star}$ & $2 \cdot 4$ & $22 \cdot 8^{\star *}$ & 1.5 \\
\hline
\end{tabular}

Mean values were significantly different from those of the control group (ANOVA followed by Dunnett's test): ${ }^{*} P<0.05,{ }^{\star \star} P<0.001$. 
$7 \beta$-hydroxysitosterol or 7-ketositosterol significantly decreased $(P<0.001)$ the viable cells to 55 and $74 \%$ and significantly increased $(P<0 \cdot 001)$ apoptotic nuclei to 25 and $26 \%$, respectively. Neither $\alpha$-tocopherol nor $\gamma$-tocopherol offered protection against the toxicity induced by either of these oxides. Furthermore, increasing the concentration of the tocopherols to $100 \mu \mathrm{M}$ did not confer protection against the POP (data not shown). $\beta$-Carotene $(2 \mu \mathrm{M})$ did not protect against COP- or POP-induced toxicity.

\section{Effect of $\beta$-sitosterol oxides on the antioxidant status of U937 cells}

To determine the antioxidant status of U937 cells, the cellular glutathione levels were measured. A significant decrease $(P<0.05)$ in glutathione content was evident following incubation with $120 \mu \mathrm{M} 7 \beta$-hydroxysitosterol for $24 \mathrm{~h}$ (Table 4). At $30 \mu \mathrm{M}$, $7 \beta$-hydroxycholesterol and triolcholesterol caused a significant reduction in glutathione content to $67 \%(P<0.001)$ and $57 \%$ $(P<0.05)$ of control, respectively. None of the other compounds affected the glutathione status of the cell.

\section{Discussion}

A limited number of studies have compared the biological effects of COP and POP. Kakis et al. (1977) showed that 7-ketocholesterol inhibited cholesterogenesis by $20-30 \%$, whereas 7-ketositosterol had no effect. Oxides of cholesterol and a $\beta$-sitosterolcampesterol mixture exhibited similar patterns of toxicity as indicated by lactate dehydrogenase leakage, cell viability and mitochondria dehydrogenase activity in a cultured macrophage cell line (C57BL/6; Adcox et al. 2001). In a more recent study, Maguire et al. (2003) concluded that the cytotoxic effects of a mixture of POP in U937 cells closely resemble those of the COP $7 \beta$-hydroxycholesterol, although higher concentrations of the POP mixture were required. However, it should be noted

Table 4. Glutathione concentration in U937 cells, expressed as a percentage of control, following exposure for $24 \mathrm{~h}$ to $120 \mu \mathrm{M} \quad \alpha$-epoxysitosterol ( $\alpha$-epox), $\beta$-epoxysitosterol ( $\beta$-epox), $\alpha$-epoxysitosterol- $\beta$-epoxysitosterol $(6: 1)$ mixture $(\alpha / \beta$-epox), $7 \beta$ hydroxysitosterol $(7 \beta-\mathrm{OH}), 7$-ketositosterol (7-keto) or triolsitosterol (triol). Cells were also treated with $30 \mu \mathrm{M}$ of the corresponding cholesterol oxides (chol)

(Values are means with their standard errors of at least three independent experiments)

\begin{tabular}{|c|c|c|c|c|}
\hline \multirow[b]{3}{*}{ Compound } & \multicolumn{4}{|c|}{$\begin{array}{c}\text { Glutathione content (\% of control) in } \\
\text { U937 cells }\end{array}$} \\
\hline & \multicolumn{2}{|c|}{$120 \mu \mathrm{M}$} & \multicolumn{2}{|c|}{$30 \mu \mathrm{M}$ chol } \\
\hline & Mean & SE & Mean & SE \\
\hline$\alpha$-epox & $101 \cdot 5$ & 3.0 & 94.5 & $2 \cdot 8$ \\
\hline$\beta$-ерох & $89 \cdot 4$ & $9 \cdot 3$ & 89.9 & $5 \cdot 3$ \\
\hline$\alpha / \beta-$ epox & $143 \cdot 2$ & 8.5 & - & - \\
\hline $7 \beta-\mathrm{OH}$ & $65 \cdot 0^{*}$ & $5 \cdot 3$ & $66 \cdot 8^{* *}$ & 1.5 \\
\hline 7-keto & 74.9 & $2 \cdot 3$ & $90 \cdot 5$ & 2.9 \\
\hline Triol & 94.7 & $6 \cdot 6$ & $57 \cdot 2^{*}$ & 11.0 \\
\hline
\end{tabular}

Mean values were significantly different from those of the control group (ANOVA followed by Dunnett's test): ${ }^{*} P<0.05$, ${ }^{\star \star} P<0.001$ that practically all of the toxicity studies carried out to date have involved the use of mixtures of phytosterol oxides. To establish the hierarchy of toxicity of these oxides, it is critical to investigate the biological activity of single purified POP. Until recently, a barrier to progress in this area was the lack of availability of pure phytosterol oxides. In the present study the cytotoxicity of pure $\beta$-sitosterol oxides, synthesised as outlined (p. 444), was investigated. Results indicate that individual oxides of $\beta$-sitosterol exhibit similar patterns of toxicity as the corresponding COP in the three cell lines employed.

The $\beta$-sitosterol oxides 7-ketositosterol and 7 $\beta$-hydroxysitosterol, oxidised at the $\mathrm{C}-7$ position, were found to be the most cytotoxic to the U937, CaCo-2 and HepG2 cell lines (Table 1). Several in vitro studies have reported that 7-ketocholesterol and $7 \beta$-hydroxycholesterol are potent inducers of apoptosis in human vascular cells, i.e. artery smooth muscle cells, endothelial cells and monocyte-macrophages (Leonarduzzi et al. 2002) and thus may have a putative role in the pathogenesis of atherosclerosis. In the present study, 7-ketositosterol and 7 $\beta$-hydroxysitosterol, albeit at higher concentrations compared with the corresponding COP, induced apoptosis in U937 cells (a monocytic cell line) as determined by Hoechst staining and DNA ladders.

Cholestane-3 $\beta, 5 \alpha, 6 \beta$-triol (triolcholesterol) is reported to be one of the most cytotoxic oxysterols towards rabbit aortic smooth muscle cells (Peng et al. 1979), mouse L cells (Higley \& Taylor, 1984) and Chinese hamster V79 lung fibroblasts (Sevanian \& Peterson, 1986) and its involvement in atherosclerosis has been investigated (Jacobson et al. 1985; Matthias et al. 1987). We report similar findings. Triolcholesterol was the most toxic oxide towards the three cell lines under investigation. The triol derivative of sitosterol was also found to be cytotoxic to the U937, CaCo-2 and HepG2 cells and induced apoptosis in the U937 cells. However, triolcholesterol was found to be more toxic than the triolsitosterol. Meyer \& Spitellier (1997) observed an increase in phytosterol epoxides and triols in photoautotrophic cell cultures during ageing. Using cholesterol epoxides and triolcholesterol as standards of known bioactivity, the same authors studied the cytotoxicity of 5,6-epoxides of sitosterol and stigmasterol and derived 3,5,6-trihydroxyphytosteranes in mealworms (Meyer et al. 1998). They reported that all compounds were toxic, in particular, the $3 \beta, 5 \alpha, 6 \beta$-trihydroxyphytosterols. However, the phytosterol derivatives were found to be less active than the corresponding COP.

Results of the present study indicate that $\alpha$-epoxysitosterol, an isomer of $\beta$-epoxysitosterol, was not toxic to the cell lines employed in this study. It had no effect on cell viability or induction of apoptosis, nor was any DNA laddering evident. Similarly, Maguire et al. (2003) reported that the $\alpha$-epoxide derivative of sitosterol failed to induce apoptosis and was not cytotoxic to U937 cells. While the $\alpha$-epoxysterol was synthesised from the parent compound $\beta$-sitosterol (60\% purity) and all other compounds employed in the press study were derived from $\beta$-sitosterol (99\% purity), our findings are consistent with results reported by O'Callaghan et al. (2001) for the corresponding cholesterol oxide. In contrast, the present study found the $\alpha$-epoxysitosterol- $\beta$-epoxysitosterol mixture (6:1) to be cytotoxic to the CaCo-2 and HepG2 cells and induced apoptosis in the U937 cells as indicated by Hoechst staining and DNA ladders. The $\beta$-epoxide isomer of sitosterol induced cytotoxicity and apoptosis in the U937 cells; however, the level of apoptosis was not great enough to produce a ladder-like pattern on agarose gel (Fig. 1). 
It has been proposed that the $\beta$-epoxide isomer of cholesterol is metabolised to triolcholesterol twice as rapidly as the $\alpha$-epoxide isomer, which may explain the difference in toxicity between these two isomeric forms (Peterson et al. 1988). A similar situation may pertain to the corresponding $\alpha$ - and $\beta$-epoxysitosterol isomers.

Whilst 7 $\beta$-hydroxysitosterol, 7-ketositosterol and triolsitosterol were found to be cytotoxic to $\mathrm{CaCo}-2$ and $\mathrm{HepG} 2$ cells, these compounds failed to induce apoptosis in both cell lines. Similarly, O'Callaghan et al. (2002) reported that $7 \beta$-hydroxycholesterol induced apoptosis in U937 cells but not in HepG-2 cells as indicated by morphological examination, flow cytometry and DNA laddering techniques. Therefore, it can be concluded that the cells died by necrosis rather than apoptosis. Lizard et al. (1999) also observed a cell-specific effect for 7 $\beta$-hydroxycholesterol and 7-ketocholesterol, which were shown to induce apoptosis in vascular endothelial and vascular smooth muscles cells but necrosis in human fibroblasts.

It has been reported that glutathione depletion precedes and may be one of the earliest events in oxysterol-induced apoptosis (Lizard et al. 1998). In the present study, a reduction in cellular glutathione was observed following incubation for $24 \mathrm{~h}$ with $120 \mu \mathrm{M} 7 \beta$-hydroxysitosterol and $30 \mu \mathrm{M}$ of the corresponding COP (Table 4). Not all oxides that induced apoptosis in the present study affected glutathione status, indicating that POP- or COP-induced apoptosis may not be dependent on the generation of an oxidative stress. Similarly, Therond et al. (2000) reported that oxysterols may have a cytotoxic effect independent of the glutathione status of the cell.

Vitamin E, in particular $\alpha$-tocopherol, has been shown to protect against lipid peroxidation (Buttriss \& Diplock, 1988) and may also protect against oxysterol-induced cytotoxicty in vitro (Lizard et al. 2000; Lyons et al. 2001; Rosenblat \& Aviram, 2002). In the present study, $\alpha$ - and $\gamma$-tocopherol inhibited $7 \beta$-hydroxycholesterol-induced cytotoxicity and apoptosis in U937 cells. Lyons et al. (2001) report that, despite a greater incorporation of $\gamma$-tocopherol into U937 cells, $\alpha$-tocopherol, but not $\gamma$-tocopherol was more effective at inhibiting $7 \beta$-hydroxycholesterol-induced apoptosis in the U937 cell culture model. In the latter study, cells were exposed to treatment for $48 \mathrm{~h}$ while the incubation period used in the present study was $24 \mathrm{~h}$. It is possible that the protection seen by $\gamma$-tocopherol in the present study is lost after $48 \mathrm{~h}$. Although $\gamma$-tocopherol is rapidly taken up by cells in culture, it also disappears more quickly than $\alpha$-tocopherol and is present at much lower levels in plasma (Tran \& Chan, 1992). Similarly, Uemura et al. (2002) found that apoptosis induced by $7 \beta$-hydroxycholesterol and 7-ketocholesterol in vascular endothelial cells was prevented by $\alpha$-tocopherol. These authors suggest that $\alpha$-tocopherol was protective not only by scavenging reactive oxygen species but also by inhibiting caspase activity. In contrast, results from the present study indicate that $\alpha / \gamma$-tocopherol did not confer protection against $7 \beta$-hydroxysitosterol- or 7-ketositosterol-induced cytotoxicity and apoptosis in U937 cells (Table 3). It may be that different apoptotic pathways are provoked by COP $v$. POP in spite of their structural similarity. We have, for example, previously shown that different COP (7 $\beta$-hydroxycholesterol $v$. $\beta$-epoxycholesterol) provoked apoptosis by different signalling pathways (Ryan et al. 2004a). Trolox (a water-soluble synthetic analogue of $\alpha$-tocopherol) protected against $7 \beta$-hydroxycholesterol-induced apoptosis but did not protect against cell death induced by $\beta$-epoxycholesterol (Ryan et al. 2004a). Clearly, more research is required to further elucidate this interesting difference between COP- and POP-induced apoptosis.

Carotenoids have been implicated as important dietary nutrients having antioxidant potential and their beneficial effects in human disease prevention have been widely reported (Tapiero et al. 2004). It is known that certain COP, e.g. $7 \beta$-hydroxycholesterol, are able to induce oxidative stress in cells (Miguet-Alfonsi et al. 2002; Ryan et al. 2004b). Therefore, we examined whether the carotenoid $\beta$-carotene would protect against COP- and POP-induced cellular toxicities. In contrast to the tocopherols, $\beta$-carotene did not confer any protection against either COP- or POP-induced cellular damage (Table 3). Studies to date suggest that the antioxidant activity of carotenoids most likely involves the scavenging of two reactive oxygen species, singlet molecular oxygen and peroxyl radicals. On the other hand, oxidative stress induced by $7 \beta$-hydroxycholesterol has been associated with alterations in superoxide dismutase activity and glutathione concentration (Ryan et al. 2004b) and stimulation of superoxide anion production (Miguet-Alfonsi et al. 2002).

In conclusion, our data represent the first direct comparison of COP and POP with respect to cytotoxicity and effects on apoptosis. POP have qualitatively similar toxic effects to COP. However, from a quantitative perspective, higher concentrations of POP are required to elicit comparable degrees of cytotoxicity and modulatory effects on apoptosis. In addition, there may be slight differences in the apoptotic pathways provoked by these oxides. In light of the increasing intakes of phytosterols due to the proliferation of phytosterol-enriched foods, further investigation of the potential toxicity of POP is warranted.

\section{Acknowledgements}

This work was supported by an Enterprise Ireland Basic Research Grant.

\section{References}

Adcox C, Boyd L, Oehrl L, Allen J \& Fenner G (2001) Comparative effects of phytosterol oxides and cholesterol oxides in cultured macrophage-derived cell lines. J Agric Food Chem 49, 2090-2095.

Aringer L, Eneroth P \& Nordstrom L (1976) Side chain hydroxylation of cholesterol, campesterol, and $\beta$-sitosterol in rat liver. J Lipid Res $\mathbf{1 7}$, $263-272$.

Berger A, Jones PJH \& Abumweis SS (2004) Plant sterols: factors affecting their efficacy and safety as functional food ingredients. http://www. lipidworld.com/content/3/1/5.

Borenfreund E \& Puerner JA (1984) A simple quantitative procedure using monolayer cultures for cytotoxicity assay (HTD/NR-90). J Tissue Cult Methods 9, 7-9.

Brown AJ \& Jessup W (1999) Oxysterols and atherosclerosis. Atherosclerosis 142, 1-28.

Buttriss JL \& Diplock AT (1988) The $\alpha$-tocopherol and phospholipids fatty acid content of rat liver subcellular membranes in vitamin E and selenium deficiency. Biochim Biophys Acta 963, 61-69.

De Jong N, Pijpers L, Bleeker JK \& Ocke MC (2004) Potential intake of phytosterols/stanols: results of a simulation study. Eur J Clin Nutr 58, 907-919.

De Jong N, Plat J \& Mensink RP (2003) Metabolic effects of plant sterols and stanols. $J$ Nutr Biochem 14, 362-369. 
Dubrez L, Savoy I, Hamman A \& Solary E (1996) Pivotal role of a DEVD-sensitive step in etopside-induced and FAS mediated apoptotic pathways. EMBO J 15, 5504-5512.

Dutta PC (1997) Studies on phytosterol oxides: 2. Content in some vegetable oils and in french fries prepared in these oils. $J$ Am Oil Chem Soc 74, 659-666.

Dutta PC \& Appelqvist LA (1997) Studies on phytosterol oxides: 1. Effect of storage on the content in potato chips prepared in different vegetable oils. J Am Oil Chem Soc 74, 647-657.

Emanuel HA, Hassel CA, Addis PB, Bergmann SD \& Zavoral JH (1991) Plasma cholesterol oxidation products (oxysterols) in human subjects fed a meal rich in oxysterols. J Food Sci 56, 843-847.

Grandgirard A (2002) Biological effects of phytosterol oxidation products, future research and concluding remarks. In Cholesterol and Phytosterol Oxidation Products, Analysis, Occurrence, and Biological Effects, pp. 375-382 [F Guardiola, PC Dutta, R Codony and GP Savage, editors]. Champaign, IL: AOCS Press.

Grandgirard A, Martine L, Demaison L, Cordelet C, Joffre C, Berdeaux O \& Semon E (2004) Oxyphytosterols are present in plasma of healthy human subjects. Br J Nutr 91, 101-106.

Grandgirard A, Sergiel JP, Nour M, Demaison-Meloche J \& Ginies C (1999) Lymphatic absorption of phytosterol oxides in rats. Lipids 34, $563-570$.

Higley NA \& Taylor SL (1984) The steatotic and cytotoxic effects of cholesterol oxides in cultured L cells. Food Chem Toxicol 22, 983-992.

Hissin PJ \& Hilf R (1976) A fluorometric method for determination of oxidised and reduced glutathione in tissues. Anal Biochem 74, 214-226.

Jacobson MS, Price MG, Shamoo AE \& Heald FP (1985) Atherogenesis in white carneau pigeons: effects of low-level cholestane-triol feeding. Atherosclerosis 57, 209-217.

Kakis G, Kuksis A \& Myher JJ (1977) Injected 7-oxycholesterol and plant sterol derivatives and hepatic cholesterogenesis. Adv Exp Med Biol 82, 297-299.

Lee K, Herian AM \& Higley NA (1985) Sterol oxidation products in french fries and in stored potato chips. J Food Protect 48, 158-161.

Leonarduzzi G, Sottero B \& Poli G (2002) Oxidised products of cholesterol: dietary and metabolic origin, and proatherosclerotic effects. $J$ Nutr Biochem 13, 700-710.

Li S \& Wilson WK (1999) Sterol synthesis. Preparation and characterization of fluorinated and deuterated analogs of oxygenated derivatives of cholesterol. Chem Phys Lipids 99, 33-71.

Lizard G, Gueldry S, Sordet O, Monier S, Athias A, Miguet C, Bessede G, Lemaire S, Solary E \& Gambert P (1998) Glutathione is implied in the control of 7-ketocholesterol-induced apoptosis, which is associated with radical oxygen species production. FASEB J 12, 1651-1663.

Lizard G, Miguet C, Bessede G, Monier S, Gueldry S, Neel D \& Gambert P (2000) Impairment with various antioxidants of the loss of mitochondrial transmembrane potential of cytosolic release of cytochrome c occulting during 7-ketocholesterol-induced apoptosis. Free Radic Biol Med 28, 743-753.

Lizard G, Monier S, Cordelet C, Gesquiere L, Deckert V, Gueldry S, Lagrost L \& Gambert P (1999) Characterisation and comparison of the mode of cell death, apoptosis versus necrosis, induced by $7 \beta$-hydroxycholesterol and 7-ketocholesterol in the cells of the vascular wall. Arterioscler Thromb Vasc Biol 19, 1190-1200.

Lyons N, Woods JA \& O'Brien NM (2001) $\alpha$-Tocopherol but not $\gamma$-tocopherol inhibits 7 $\beta$-hydroxycholesterol-induced apoptosis in human U937 cells. Free Radic Res 35, 329-339.

McCarthy FO, Chopra J, Ford A, Hogan SA, Kerry JP, O'Brien NM et al. (2005) Synthesis, isolation and characterisation of Baitosterol and $\beta$ sitosterol derivations. Org Biomol Chem 3, 3059.

Maguire L, Konoplyannikov M, Ford A, Maguire AR \& O'Brien NM (2003) Comparison of the cytotoxic effects of $\beta$-sitosterol oxides and a cholesterol oxide, 7 $\beta$-hydroxycholesterol, in cultured mammalian cells. Br J Nutr 90, 767-775.
Matthias D, Becker CH, Godicke W, Schmidt R \& Ponsold K (1987) Action of cholestane- $3 \beta \mathrm{a}, 5 \alpha, 6 \beta$-triol on rats with particular reference to aorta. Atherosclerosis 63, 115-124.

Meyer W, Jungnickel H, Janijke M, Dettner K \& Spitellier G (1998) On the cytotoxicity of oxidised phytosterols isolated from photoautotrophic cell cultures of Chenopodium rubrum tested on meal-worms Tenebrio molitor. Phytochemistry 47, 789-797.

Meyer W \& Spitellier G (1997) Oxidised phytosterols increase by ageing in photoautotrophic cell cultures of Chenopodium rubrum. Phytochemistry 45, 297-302.

Miguet-Alfonsi C, Prunet C, Monier S, Bessede G, Lemaire-Ewing S, Berthier A, Menetrier F, Neel D, Gambert P \& Lizard G (2002) Analysis of oxidative processes and of myelin figures formation before and after the loss of mitochondrial transmembrane potential during 7ß-hydroxycholesterol and 7-ketocholesterol-induced apoptosis: comparison with various pro-apoptotic chemicals. Biochem Pharmacol 64, 527-541.

Moreau RA, Whitaker BD \& Hicks KB (2002) Phytosterols, phytostanols, and their conjugates in foods: structural diversity, quantitative analysis, and health promoting uses. Prog Lipid Res 41, 457-500.

Mowels JM (1990) Mycoplasma detection. In Animal Cell Culture, Methods in Molecular Biology, vol. V, pp. 65-74 [JW Pollard and JM Walker, editors]. Clifton, NJ: Humana Press.

Nourooz-Zadeh J \& Appelqvist LA (1992) Isolation and quantitative determination of sterol oxides in plant-based foods: soybean oil and wheat flour. J Am Oil Chem Soc 69, 288-293.

O'Callaghan YC, Woods JA \& O'Brien NM (1999) Oxysterol-induced cell death in U937 and HepG2 cells at reduced and normal serum concentrations. Eur J Nutr 38, 255-262.

O'Callaghan YC, Woods JA \& O'Brien NM (2001) Comparative study of the cytotoxicity and apoptosis-inducing potential of commonly occurring oxysterols. Cell Biol Toxicol 7, 127-137.

O'Callaghan YC, Woods JA \& O'Brien NM (2002) Characteristics of 7 $\beta$ hydroxycholesterol-induced cell death in a human monocytic blood cell line, U937, and a human hepatoma cell line, HepG2. Toxicol In Vitro 16, $245-251$.

Ostlund RE Jr (2002) Phytosterols in human nutrition. Annu Rev Nutr 22, 533-549.

Pakrashi A \& Basak B (1976) Abortifacient effect of steroids from Ananas comosus and their analogues on mice. J Reprod Fertil 46, 461-462.

Peng SK, Tham P, Taylor CB \& Mikkelson B (1979) Cytotoxicity of oxidation derivatives of cholesterol on cultured aortic smooth muscle cells and their effect on cholesterol biosynthesis. Am J Clin Nutr 32, $1033-1042$.

Peterson AR, Peterson H, Spears CP, Trosko JE \& Sevanian A (1988) Mutagenic characterisation of cholesterol epoxides in Chinese hamster V79 cells. Mutat Res 203, 355-366.

Plat J, Brzezinka H, Lutjohann D, Mensink RP \& Von Bergmann K (2001) Oxidised plant sterols in human serum and lipid infusions as measured by combined gas-liquid chromatography-mass spectrometry. J Lipid Res 42, 2030-2038.

Rosenblat M \& Aviram M (2002) Oxysterol-induced activation of macrophage NADPH-oxidase enhances cell-mediated oxidation of LDL in the atherosclerotic apolipoprotein $\mathrm{E}$ deficient mouse: inhibitory role of vitamin E. Atherosclerosis 160, 69-80.

Ryan L, O'Callaghan YC \& O'Brien NM (2004a) Comparison of the apoptotic processes induced by the oxysterols $7 \beta$-hydroxycholesterol and cholesterol-5 $\beta, 6 \beta$-epoxide. Cell Biol Toxicol 20, 313-323.

Ryan L, O'Callaghan YC \& O'Brien NM (2004b) Generation of an oxidative stress precedes caspase activation during $7 \beta$-hydroxycholesterol-induced apoptosis in U937 cells. J Biochem Mol Toxicol 18, 50-59.

Sevanian A \& Peterson AR (1986) The cytotoxic and mutagenic properties of cholesterol oxidation products. Food Chem Toxicol 24, $1103-1110$.

Smith PK, Krohn RI, Hermanson GT, Mallia AK, Gartner FH, Provenzano MD, Fujimoto EK, Goeke NM, Olson BJ \& Klenk DC 
(1985) Measurement of protein using bicinchoninic acid. Anal Biochem 150, 76-85.

Strauss GHS (1991) Non-random cell killing in cryopreservation: implications for performance of the battery of leukocyte tests (BLT), 1. Toxic and immunotoxic effects. Mutat Res 252, 1-15.

Tai CY, Chen YC \& Chen BH (1999) Analysis, formation and inhibition of cholesterol oxidation products in foods: an overview (Part 1). J Food Drug Anal 7, 243-257.

Tapiero H, Townsend DM \& Tew KD (2004) The role of carotenoids in the prevention of human pathologies. Biomed Pharmacother 58, $100-110$.

Therond P, Abella A, Laurent D, Couturier M, Chalas J, Legrand A \& Lindenbaum A (2000) In vitro study of the cytotoxicity of isolated oxidised low-density lipoprotein fractions in human endothelial cells: relationship with the glutathione status and cell morphology. Free Radic Biol Med 28, 585-596.

Tomoyori H, Kawata Y, Higuchi T, Ichi I, Sato H, Sato M, Ikeda I \& Imaizumi K (2004) Phytosterol oxidation products are absorbed in the intestinal lymphatics in rats but do not accelerate atherosclerosis in apolipoprotein-E deficient mice. J Nutr 134, 1690-1696.

Tran K \& Chan AC (1992) Comparative uptake of $\alpha$-tocopherol and $\gamma$-tocopherol by human endothelial cells. Lipids 27, 38-41.

Turchetto E, Lercker G \& Bortolomeazzi R (1993) Oxisterol determination in selected coffees. Toxicol Ind Health 9, 519-527.

Uemura M, Hiroki M, Yoshida N, Fujita N, Ochiai J, Matsumoto N, Takagi T \& Yoshikawa T (2002) $\alpha$-Tocopherol prevents apoptosis of vascular endothelial cells via a mechanism exceeding that of mere antioxidation. Eur J Pharmacol 456, 29-37. 